\title{
KARAKTERISTIK “JARING CANTRANG” YANG DIOPERASIKAN DI PERAIRAN PANTAI UTARA JAWA
}

\author{
Sawon*), Enjah Rahmat"), Suwardi*), Agus Salim*), dan Nardi H.E*). \\ *Teknisi Litkayasa pada Balai Riset Perikanan Laut, Jakarta \\ Teregristasi I tgl. 6/3/2006; Disetujui terbit tgl. 19/7/2006
}

\section{PENDAHULUAN}

Selama ini perikanan laut menyumbang devisa negara sekitar 60 sampai dengan $70 \%$ setiap tahunnya terhadap perikanan nasional. Meskipun sumber daya tersebut bersifat dapat diperbaharui, namun pemanfaatan yang tidak irrasional bisa menyebabkan penurunan sumber daya secara kualitas maupun kuantitas. Oleh karena itu, pemanfaatan sumber daya harus lebih berhati-hati dan disertai pengaturan-pengaturan agar pengupayaannya tidak melebihi batas optimal sehingga kelestariannya terjamin.

Salah satu alat tangkap ikan yang dioperasikan di perairan Pantai Utara Jawa adalah jaring cantrang. Alat tangkap tersebut bila digunakan secara berlebihan, akan merusak kelestarian sumber daya ikan. Pengusahaan ikan di perairan Pantai Utara Jawa pada umumnya menggunakan alat tangkap jaring cantrang, jaring lempara dasar, pukat cincin, pancing rawai, pancing ulur, gill net, dan trammel net. Beberapa jenis ikan demersal yang mempunyai nilai ekonomis penting antara lain kakap putih (Lates calcarifer), kerapu (Serranidae), kakap merah (Lutjanus spp.), dan gerot-gerot (Pomadasys spp.).

Tujuan penulisan makalah adalah hendak menyajikan data dan informasi mengenai dimensi teknis kapal, karakteristik alat tangkap, aspek operasional, dan biologi ikan. Penelitian dilakukan dengan pengamatan langsung terhadap jaring cantrang yang sedang beroperasi di atas KM. Bintang Jaya milik nelayan setempat.

\section{DESKRIPSI KAPAL DAN ALAT TANGKAP}

\section{Kapal}

Kapal yang dipakai untuk operasi penangkapan memakai jaring cantrang tergolong berukuran sedang.
Kapal kayu tersebut dibuat oleh galangan kapal Gesik Harjo tahun 1998. Berukuran panjang (LOA) 9,50 m, lebar (W) 3,30 m, dalam (D) 0,60 m, bobot kotor 3 GT, dengan kecepatan 5 mil per jam. Mesin dompeng merk Kubota 3 buah masing-masing 16 PK. Adapun spesifikasi kapal adalah seperti yang tersaji dalam (Tabel 1).

\section{Alat Tangkap}

Dimensi jaring cantrang di Brondong Jawa Timur pada umumnya setiap unit terbagi dalam 4 bagian utama yaitu:

1. Bagian sayap panjang $10,5 \mathrm{~m} \times 95-130$ mata

2. Bagian mulut panjang $2,0 \mathrm{~m} \times 500$ mata

3. Bagian badan panjang $5,5 \mathrm{~m} \times 350-450$ mata

4. Bagian kantong panjang $6,0 \mathrm{~m} \times 300$ mata

Adapun spesifikasi dan desain alat tangkap jaring cantrang adalah seperti yang tersaji dalam (Tabel 2 dan Gambar 1) berikut.

\section{TEKNIK PENANGKAPAN}

\section{Cara Pengoperasian}

1. Pengoperasian jaring cantrang dilakukan dengan sistem penyapuan secara horisontal, artinya posisi arah kapal dari mulai penurunan sampai dengan penarikan 1 arah dan setelah selesai penurunan langsung dilakukan penarikan.

2. Penurunan jaring cantrang yang diawali dengan bagian kantong dilakukan setiap kapal sampai pada posisi yang dituju, tidak tergantung waktu dan jam baik malam maupun siang hari.

3. Lama penurunan jaring sekitar antara 10 sampai dengan 15 menit per settingnya.

4. Setelah penurunan jaring cantrang selesai langsung dilakukan penarikan yang waktunya antara 15 sampai dengan 30 menit untuk per setting. 
Tabel 1. Data spesifikasi kapal KM. Bintang Jaya di Brondong Jawa Timur bulan September 2002

\begin{tabular}{|c|c|c|}
\hline No. & SPESIFIKASI & KETERANGAN \\
\hline 1 & Nama nahkoda & Janji waras \\
\hline 2 & Nama kapal & Bintang Jaya \\
\hline 3 & Tipe/jenis & Compreng \\
\hline 4 & Alat tangkap & Cantrang \\
\hline 5 & Dari TPI & Brondong \\
\hline 6 & Bahan utama & Kayu \\
\hline 7 & Tempat pembuatan & Gesik Harjo \\
\hline 8 & Tahun pembuatan & Tahun 1998 \\
\hline 9 & Panjang (LOA) & $9,50 \mathrm{~m}$ \\
\hline 10 & Lebar (W) & $3,30 \mathrm{~m}$ \\
\hline 11 & Dalam (D) & $0,60 \mathrm{~m}$ \\
\hline 12 & Bobot kotor (GT) & $3 \mathrm{GT}$ \\
\hline 13 & Mesin utama & Dompeng 3 buah masing-masing $16 \mathrm{PK}$ \\
\hline 14 & Mesin bantu & Dompeng $16 \mathrm{PK}$ (untuk gardan) \\
\hline 15 & Alat penarik & Gardan \\
\hline 16 & Jenis kayu & Bungur \\
\hline 17 & Ukuran lunas & $16 \mathrm{~cm} \times 24 \mathrm{~cm} \times 900 \mathrm{~cm}$ \\
\hline 18 & Ukuran gading & $8 \mathrm{~cm} \times 16 \mathrm{~cm} \times 200 \mathrm{~cm}$ \\
\hline 19 & Ukuran papan & $3 \mathrm{~cm} \times 20 \mathrm{~cm} \times 400 \mathrm{~cm}$ \\
\hline 20 & Jenis palkah ikan & Kotak berisolasi \\
\hline 21 & Lapisan luar & Papan dan seng \\
\hline 22 & Lapisan tengah & Plastik dan styrofoam \\
\hline 23 & Lapisan dalam & Plastik dan seng \\
\hline 24 & Harga kasko & Rp.65.000.000,- \\
\hline 25 & Harga mesin & Rp.20.000.000,- (4 buah) \\
\hline 26 & Lampu & Petromaks \\
\hline 27 & Jumlah ABK & 5 orang \\
\hline 28 & Lama di laut rata-rata/trip & 1 sampai dengan 5 hari \\
\hline
\end{tabular}

Tabel 2. Data spesifikasi alat tangkap jaring cantrang KM. Bintang Jaya di Brondong Jawa Timur bulan September 2002

\begin{tabular}{|c|c|c|}
\hline No. & SPESIFIKASI & KETERANGAN \\
\hline 1 & Jenis alat tangkap & Jaring cantrang \\
\hline 2 & Jumlah unit & 1 unit \\
\hline \multirow[t]{14}{*}{3} & Bagian sayap (A) & Panjang $10,5 \mathrm{~m} \times 95-130$ mata \\
\hline & -Tali ris atas & PE $10 \mathrm{~mm} \times 10,5 \mathrm{~m}$ \\
\hline & -Tali ris bawah & $\mathrm{PE} 12 \mathrm{~mm} \times 11,5 \mathrm{~m}$ \\
\hline & -Rantai ris bawah & Timah $(\mathrm{Pb}) 25 \mathrm{~kg}$ \\
\hline & -Pelampung bulat & Plastik $5 \mathrm{~cm}(\mathrm{n})=40$ buah \\
\hline & -Tali pengotot & PE $5 \mathrm{~mm} \times 1 \mathrm{~m}$ \\
\hline & -Mata jaring (panjang) & PE $13 / 4 " . d .9 \times 10,5 \mathrm{~m} \times 95-130$ mata \\
\hline & -Tali cabang atas & PE $10 \mathrm{~mm} \times 1 \mathrm{~m}$ \\
\hline & -Tali cabang bawah & $\mathrm{PE} 14 \mathrm{~mm} \times 2 \mathrm{~m}$ \\
\hline & -Danleno (2 buah) & Papan $3 \mathrm{~cm} \times 30 \mathrm{~cm} \times 70 \mathrm{~cm}$ \\
\hline & -Rantai atas danleno & Baja $1,0 \mathrm{~m}$ \\
\hline & -Rantai bawah danleno & Baja $1,40 \mathrm{~m}$ \\
\hline & -Swivel stainlis (2 buah) & Panjang $15 \mathrm{~cm}$ \\
\hline & -Tali selambar (2 buah) & $\mathrm{PE} 30 \mathrm{~mm} \times 200 \mathrm{~m}$ \\
\hline \multirow[t]{5}{*}{4} & Bagian mulut (B) & Panjang $2,0 \mathrm{~m}$ x 500 mata \\
\hline & -Tali ris atas & PE $10 \mathrm{~mm} \times 2,0 \mathrm{~m}$ \\
\hline & -Tali ris bawah & $\mathrm{PE} 12 \mathrm{~mm} \times 2,5 \mathrm{~m}$ \\
\hline & -Pelampung bulat & Plastik $5 \mathrm{~cm}(\mathrm{n})=3$ buah \\
\hline & -Mata jaring (panjang) & PE $13 / 4 " . d .9 \times 2,0 \mathrm{~m} \times 500$ mata \\
\hline \multirow[t]{5}{*}{5} & Bagian badan $(\mathrm{C})$ & Panjang $5,5 \mathrm{~m} \times 350-450$ mata \\
\hline & -Tali ris atas & PE $10 \mathrm{~mm} \times 5,5 \mathrm{~m}$ \\
\hline & -Tali ris bawah & PE $12 \mathrm{~mm} \times 6,5 \mathrm{~m}$ \\
\hline & -Mata jaring (panjang) & PE 1 1/2".d.9 x 2,0 m x 450 mata \\
\hline & -Mata jaring (panjang) & PE 1".d.12 x 3,5 m x 350-400 mata \\
\hline \multirow[t]{8}{*}{6} & Bagian kantong (D) & Panjang $6,0 \mathrm{~m} \times 300$ mata \\
\hline & -Tali ris atas & PE $10 \mathrm{~mm} \times 6,0 \mathrm{~m}$ \\
\hline & -Tali ris bawah & $\mathrm{PE} 12 \mathrm{~mm} \times 7,0 \mathrm{~m}$ \\
\hline & -Tali pengikat & PE $3 \mathrm{~mm}$ \\
\hline & -Tali pengaman & PE $12 \mathrm{~mm} \times 28 \mathrm{~m}$ \\
\hline & -Pelampung bulat & Plastik $15 \mathrm{~cm}$ \\
\hline & -Mata jaring (panjang) & PE 1".d. 12 x 6,0 m x 300 mata \\
\hline & -Mata jaring (keliling) & PE 1".d. 12 x 300 mata \\
\hline
\end{tabular}




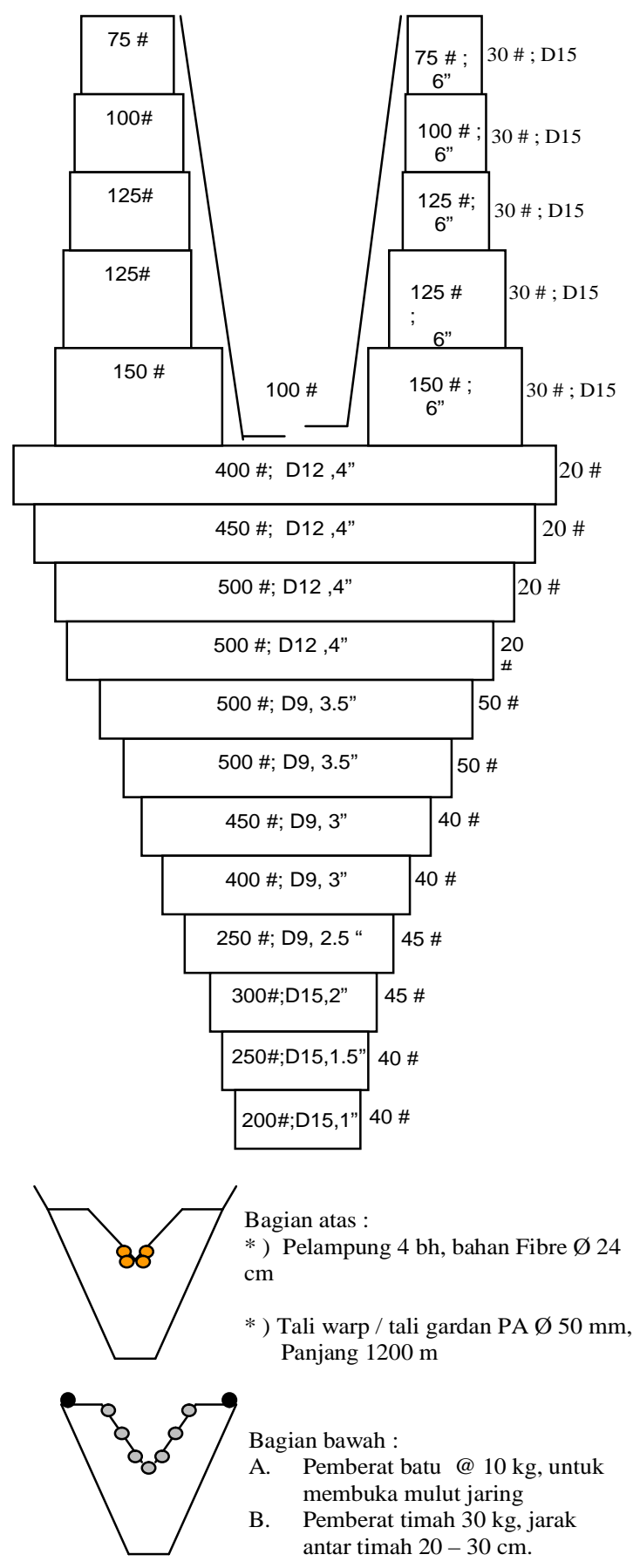

Gambar 1. Desain alat tangkap jaring cantrang.

5. Pada ke dua ujung sayap jaring cantrang dipasang danleno (other) dari papan dengan ukuran $3 \mathrm{~cm} x$ $30 \mathrm{~cm} \times 70 \mathrm{~cm}$, yang berfungsi untuk membuka kedua sayap tersebut.

6. Penarikan jaring cantrang dilakukan dengan alat bantu pemutar dari gardan menggunakan tenaga dari mesin bantu.

7. Pengemasan ikan hasil tangkapan dilakukan dengan cara memasukkannya ke dalam peti berisolasi dan diberi es balok.

\section{HASIL TANGKAPAN}

\section{Laju Tangkap}

Hasil tangkapan keseluruhan jaring cantrang KM. Bintang Jaya pada bulan September 2002 dari 33 kali setting sebanyak $5.496,5 \mathrm{~kg}$, tersaji pada (Tabel 3). Dengan demikian, laju tangkap rata-rata $166,56 \mathrm{~kg}$ atau $3,03 \%$. Laju tangkap tertinggi pada posisi 0645'37" LS-112²3'54" BT (setting ke-22) pada pukul 
Tabel 3. Data operasional dan hasil tangkapan jaring cantrang KM. Bintang Jaya di Brondong Jawa Timur bulan September 2002

\begin{tabular}{|c|c|c|c|c|c|c|c|c|c|c|c|}
\hline \multirow{2}{*}{ Sett. } & \multicolumn{2}{|c|}{ Posisi } & \multirow{2}{*}{$\begin{array}{l}\text { Kdlm. } \\
(\mathbf{m})\end{array}$} & \multicolumn{3}{|c|}{ Oseanografi } & \multicolumn{2}{|c|}{ Jam } & \multirow{2}{*}{$\begin{array}{c}\text { Penarikan } \\
\text { (menit) }\end{array}$} & \multirow{2}{*}{$\begin{array}{l}\text { Jml. Kapal } \\
\text { di sekitarnya }\end{array}$} & \multirow{2}{*}{$\begin{array}{l}\text { Hs..Tangkapan } \\
(\mathbf{k g})\end{array}$} \\
\hline & LS & BT & & Suhu & Salinitas & $\begin{array}{c}\text { Tali } \\
\text { Plankton (m) } \\
\end{array}$ & Setting & Haulling & & & \\
\hline 1 & 060.44'.08" & $112^{\circ} .24^{\prime} .57^{\prime \prime}$ & 35,0 & 26 & 38 & 15 & $05.35-05.45$ & 05.50 - 06.15 & 25 & 25 & 75,0 \\
\hline 2 & 06.44':10" & $112^{\circ} .24^{\prime} .54^{\prime \prime}$ & 34,0 & 26 & 38 & & $06.20-06.30$ & $06.35-07.00$ & 25 & 25 & 110,5 \\
\hline 3 & 06.44':07" & $112^{\circ} .25^{\prime} .15^{\prime \prime}$ & 35,0 & 26 & 38 & & $07.05-07.15$ & $07.20-07.35$ & 15 & 25 & 116,1 \\
\hline 4 & $06^{6} .44^{\prime} .17 "$ & $112^{\circ} .24^{\prime} .19^{\prime \prime}$ & 36,0 & 27 & 39 & & $07.50-08.05$ & $08.10-08.30$ & 20 & 23 & 136,3 \\
\hline 5 & $060.45 \cdot .17 "$ & $112^{0} .24^{\prime} .24^{\prime \prime}$ & 36,5 & 27 & 39 & & $08.35-08.45$ & $08.50-09.10$ & 20 & 24 & 131,1 \\
\hline 6 & $06^{0} .45 \cdot .25^{\prime \prime}$ & $112^{\circ} .24^{\prime} .34^{\prime \prime}$ & 36,5 & 28 & 38 & 21 & $09.15-09.25$ & $09.30-09.50$ & 20 & 29 & 146,2 \\
\hline 7 & $06^{0} .45^{\prime} .59^{\prime \prime}$ & $112^{\circ} .24^{\prime} .15^{\prime \prime}$ & 35,5 & 28 & 38 & & $10.00-10.10$ & $10.15-10.35$ & 20 & 32 & 145,8 \\
\hline 8 & $06^{0} .46^{\prime} .05^{\prime \prime}$ & 1120.24'.15" & 36,5 & 28 & 38 & & $10.40-10.50$ & $10.55-11.15$ & 20 & 21 & 145,5 \\
\hline 9 & $060.45 \cdot .58 "$ & $112^{\circ} .23^{\prime} .50^{\prime \prime}$ & 36,0 & 28 & 38 & & $11.20-11.30$ & $11.35-11.55$ & 20 & 18 & 126,2 \\
\hline 10 & $060.45 \cdot .51 "$ & 1120.23'.41" & 36,5 & 28 & 38 & & $12.00-12.10$ & $12.15-12.35$ & 20 & 16 & 121,3 \\
\hline 11 & $060.45 \cdot .59 "$ & 1120.23'.51" & 36,5 & 28 & 38 & & $12.40-12.50$ & $12.55-13.15$ & 20 & 10 & 170,8 \\
\hline 12 & 06.44'.11" & $112^{\circ} .24^{\prime} .59^{\prime \prime}$ & 35,5 & 26 & 38 & 20 & $05.30-05.40$ & $05.45-06.05$ & 20 & 36 & 195,5 \\
\hline 13 & $06^{0} .44 \cdot 15^{\prime \prime}$ & $112^{\circ} .24^{\prime} .58^{\prime \prime}$ & 34,5 & 26 & 38 & & $06.10-06.20$ & $06.25-06.45$ & 20 & 36 & 187,3 \\
\hline 14 & 06.44'.16" & $112^{\circ} .25^{\prime} .35^{\prime \prime}$ & 35,5 & 26 & 38 & & $06.50-07.00$ & $07.05-07.25$ & 20 & 35 & 180,6 \\
\hline 15 & $06^{0} .44^{\prime} .39 "$ & $112^{\circ} .24^{\prime} .09^{\prime \prime}$ & 36,5 & 27 & 39 & & $07.30-07.40$ & $07.45-08.05$ & 20 & 35 & 185,5 \\
\hline 16 & $06^{6} .45 \cdot 10^{\prime \prime}$ & 1120.24'.11" & 36,5 & 27 & 39 & & $08.10-08.20$ & $08.25-08.45$ & 20 & 34 & 175,5 \\
\hline 17 & $06^{0} .45 ' .12^{\prime \prime}$ & 1120.24':39" & 36,5 & 28 & 38 & & $08.50-09.00$ & $09.05-09.25$ & 20 & 34 & 206,1 \\
\hline 18 & 060.45'.51" & $112^{\circ} .24^{\prime} .32^{\prime \prime}$ & 35,5 & 28 & 38 & & $09.30-09.40$ & $09.45-10.05$ & 20 & 34 & 200,5 \\
\hline 19 & $06^{0} .46^{\prime} \cdot 10^{\prime \prime}$ & $112^{\circ} .24^{\prime} .25^{\prime \prime}$ & 36,0 & 28 & 38 & & $10.10-10.20$ & $10.25-10.45$ & 20 & 31 & 215,5 \\
\hline 20 & $06^{0} .45^{\prime} .52^{\prime \prime}$ & $112^{\circ} .23^{\prime} .55^{\prime \prime}$ & 36,5 & 28 & 38 & & $10.50-11.00$ & $11.05-11.25$ & 20 & 31 & 167,4 \\
\hline 21 & $060.45 \cdot .50 "$ & $112^{\circ} .23^{\prime} .44^{\prime \prime}$ & 36,5 & 28 & 38 & & $11.30-11.40$ & $11.45-12.05$ & 20 & 31 & 155,5 \\
\hline 22 & $06^{6} .45^{\prime} .47^{\prime \prime}$ & $112^{0} .23^{\prime} .54^{\prime \prime}$ & 36,5 & 28 & 38 & & $12.10-12.20$ & $12.25-12.45$ & 20 & 27 & 221,0 \\
\hline 23 & 060.45'.41" & $112^{\circ} .23^{\prime} .44^{\prime \prime}$ & 36,5 & 28 & 38 & 21 & $12.50-13.00$ & $13.05-13.25$ & 20 & 15 & 205,5 \\
\hline 24 & 060.44'.31" & $112^{\circ} .24^{\prime} .55^{\prime \prime}$ & 35,5 & 26 & 38 & & $05.00-05.10$ & $05.15-05.35$ & 20 & 29 & 210,5 \\
\hline 25 & $06^{0} .44^{4} \cdot 15^{\prime \prime}$ & $112^{\circ} .24^{\prime} .50^{\prime \prime}$ & 34,5 & 26 & 38 & & $05.45-05.55$ & $06.00-06.20$ & 20 & 29 & 175,0 \\
\hline 26 & 060.44'.11" & $112^{\circ} .25^{\prime} .24^{\prime \prime}$ & 35,0 & 26 & 38 & & $06.25-06.35$ & $06.40-07.00$ & 20 & 27 & 185,0 \\
\hline 27 & $06^{0} .44^{\prime} .21 "$ & $112^{\circ} .24^{\prime} .27^{\prime \prime}$ & 36,0 & 27 & 39 & & $07.10-07.20$ & $07.25-07.45$ & 20 & 25 & 171,2 \\
\hline 28 & $06^{0} .45 \cdot .23^{\prime \prime}$ & $112^{0} .24^{\prime} .36^{\prime \prime}$ & 36,5 & 27 & 39 & & $07.50-08.00$ & $08.10-08.30$ & 20 & 23 & 130,5 \\
\hline 29 & $06^{0} .45 \cdot 21 "$ & $112^{\circ} .24^{\prime} .09^{\prime \prime}$ & 36,5 & 28 & 38 & & $08.40-08.50$ & $08.55-09.15$ & 20 & 23 & 165,6 \\
\hline 30 & $06^{0} .45 \cdot 50^{\prime \prime}$ & $112^{0} .24^{\prime} .35^{\prime \prime}$ & 35,5 & 28 & 38 & 23 & $09.20-09.30$ & 09.35 - 09.55 & 20 & 21 & 220,5 \\
\hline 31 & $06^{\circ} .46^{\prime} .04^{\prime \prime}$ & $112^{\circ} .24^{\prime} .25^{\prime \prime}$ & 36,5 & 28 & 38 & & $10.05-10.15$ & $10.25-10.45$ & 20 & 21 & 185,7 \\
\hline 32 & $06^{0} .45^{\prime} .54^{\prime \prime}$ & $112^{0} .23^{\prime} .59^{\prime \prime}$ & 36,0 & 28 & 38 & & $10.50-11.00$ & $11.05-11.30$ & 25 & 16 & 175,5 \\
\hline 33 & $060.45^{\prime} .09^{\prime \prime}$ & $112^{\circ} .23^{\prime} .39^{\prime \prime}$ & 36,5 & 28 & 38 & & $11.35-11.45$ & 11.55 - 12.25 & 30 & 14 & 156,3 \\
\hline \multicolumn{3}{|c|}{ JUMLAH } & - & - & - & $=$ & - & - & - & - & $5,496,5$ \\
\hline \multicolumn{3}{|c|}{ RATA-RATA } & - & - & - & - & - & - & - & - & 166,56 \\
\hline
\end{tabular}

12.25 sampai dengan 12.45 waktu setempat dengan hasil tangkapan $221,0 \mathrm{~kg}$ atau $4,02 \%$. Sedangkan laju tangkap terendah pada posisi $06^{\circ} 44^{\prime} 08^{\prime \prime}$ LS$112^{\circ} 24^{\prime} 57^{\prime \prime}$ BT (setting ke-1) pada pukul 05.50 sampai dengan 06.15 waktu setempat dengan hasil tangkapan $75,0 \mathrm{~kg}$ atau $1,36 \%$.

\section{Komposisi}

Hasil tangkapan terdiri atas 42 jenis, dengan bobot $5.496,5 \mathrm{~kg}$, yang tersaji dalam Tabel 4 , jenis ikan yang dominan adalah ikan gulamah (Pseudociena anoyensis) $634,8 \mathrm{~kg}$ atau $11,55 \%$, ikan petek
(Leiognathus sp) $621,1 \mathrm{~kg}$ atau $11,30 \%$ dan ikan biji nangka (Upeneus sp.) 553,6 kg atau 10,07\%.

\section{Biologi dan Ukuran Ikan}

Dari hasil tangkapan jaring cantrang KM. Bintang Jaya bulan September 2002 di Brondong Jawa Timur berhasil diukur ikan sebanyak 292 ekor dengan panjang cagak $(F L)$ terkecil $=7,0 \mathrm{~cm}$ dan terbesar $=$ $72,0 \mathrm{~cm}$, panjang total $(\mathrm{TL})$ terkecil $=8,5 \mathrm{~cm}$ dan terbesar $=76,5 \mathrm{~cm}$, tinggi $\left(D_{\text {max }_{\text {max }}}\right)$ terkecil $=1,0 \mathrm{~cm}$ dan terbesar $=13,9 \mathrm{~cm}$, bobot $(W)$ terkecil $=0,01 \mathrm{~kg}$ dan terbesar $=1,56 \mathrm{~kg}$. 
Tabel 4. Komposisi hasil tangkapan jaring cantrang KM. Bintang Jaya di Brondong Jawa Timur bulan September 2002

\begin{tabular}{|c|c|c|c|c|}
\hline No. & Nama Lokal & Nama Latin & Hasil (kg) & Rata-rata (\%) \\
\hline 1 & Petek & (Leiognathus sp.) & 621,1 & 11,30 \\
\hline 2 & Ikan merah mata besar & (Priacanthus tayenus) & 136,8 & 2,49 \\
\hline 3 & Barakuda & (Sphyraena genie) & 255,5 & 4,65 \\
\hline 4 & Kuniran & (Upeneus sulphureus) & 536,2 & 9,75 \\
\hline 5 & Golok-golok & (Chirosentrus dorab) & 42,2 & 0,77 \\
\hline 6 & Kerapu & (Epinephelus sp.) & 236,0 & 4,29 \\
\hline 7 & Buntek & (Cantigaster benel) & 28,5 & 0,52 \\
\hline 8 & Sebelah & (Cynoglossus sp.) & 98,1 & 1,78 \\
\hline 9 & Kakap merah & (Lutjanus altifrontalis) & 119,5 & 2,17 \\
\hline 10 & Gulamah & (Pseudociena anoyensis) & 634,8 & 11,55 \\
\hline 11 & Kerong-kerong & (Therapon theraps) & 160,5 & 2,92 \\
\hline 12 & Beloso & (Saurida tumbil) & 283,6 & 5,16 \\
\hline 13 & Bondolan & (Leiognathus splendeus) & 115,0 & 2,09 \\
\hline 14 & Cumi-cumi & (Loligo sp.) & 52,0 & 0,95 \\
\hline 15 & Sotong & (Loligo sp.) & 7,0 & 0,13 \\
\hline 16 & Bulu ayam & (Thryssa setirostris) & 3,2 & 0,06 \\
\hline 17 & Kepiting & (Portunus sp.) & 64,1 & 1,17 \\
\hline 18 & Kapas-kapas & (Achanturus sp.) & 131,3 & 2,39 \\
\hline 19 & Kurisi & (Nemipterus nematophosus) & 322,1 & 5,86 \\
\hline 20 & Kakap batu & (Lutjanus sp.) & 3,2 & 0,06 \\
\hline 21 & Bilis & (Stolephorus sp.) & 25,4 & 0,46 \\
\hline 22 & Cucut & (Chiloscyllium griseum) & 3,8 & 0,07 \\
\hline 23 & Layur & (Trichiurus savala) & 45,4 & 0,83 \\
\hline 24 & Sewanggi & (Priachautus sp.) & 221,5 & 4,03 \\
\hline 25 & Bambangan & (Lutjanus sanguineus) & 64,0 & 1,16 \\
\hline 26 & Kuro & (Eletheronema titradaetylena) & 3,2 & 0,06 \\
\hline 27 & Cucut martil & (Sphyrna zygaena) & 14,3 & 0,26 \\
\hline 28 & Biji nangka & (Upeneus sp.) & 553,6 & 10,07 \\
\hline 29 & Triger & (Chaetodonsp.) & 4,2 & 0,08 \\
\hline 30 & Lencam & (Lethrinus lentjam) & 238,4 & 4,34 \\
\hline 31 & Pari & (Arhynchobatidae) & 166,9 & 3,04 \\
\hline 32 & Sardinella & (Sardinella longiceps) & 67,8 & 1,23 \\
\hline 33 & Baji-baji & (Saurida sp.) & 13,4 & 0,24 \\
\hline 34 & Selar & (Selaroides leptoleppis) & 72,3 & 1,32 \\
\hline 35 & Skutor & (Leiognathus sp.) & 40,6 & 0,74 \\
\hline 36 & Remang/belut & (Congresox talabon) & 64,7 & 1,18 \\
\hline 37 & Kiper & (Siganus sp.) & 32,2 & 0,58 \\
\hline 38 & Lepo ayam & (Pterais antenata) & 2,2 & 0,04 \\
\hline 39 & Udang jerbung & (Penaeus merguiensis) & 2,9 & 0,05 \\
\hline 40 & Udang kelong & (Penaeus indicus) & 1,8 & 0,03 \\
\hline 41 & Udang bago & (Penaeus semisulcatus) & 3,0 & 0,05 \\
\hline \multirow[t]{3}{*}{42} & Udang cakrik & (Lysiosquilla maculata) & 4,3 & 0,08 \\
\hline & JUMLAH & & $5.496,5$ & 100,00 \\
\hline & RATA-RATA & & 166,56 & 2,38 \\
\hline
\end{tabular}


Kisaran dan frekuensi panjang total (TL), dan tinggi badan ikan (D. ${ }_{\text {max }}$ ) hasil tangkapan jaring cantrang KM. Bintang Jaya bulan September 2002 di Brondong Jawa Timur berhasil diukur ikan sebanyak 292 ekor, dengan kisaran panjang total (TL) terkecil antara 01 sampai dengan $10 \mathrm{~cm}$ dan terbesar antara 71 sampai dengan $80 \mathrm{~cm}$. Sedang kisaran tinggi badan ikan (D. ${ }_{\max }$ ) terkecil antara 01 sampai dengan $10 \mathrm{~cm}$ dan tertinggi antara 11 sampai dengan $20 \mathrm{~cm}$, yang tersaji dalam (Tabel 5).

Tabel 5. Data sebaran panjang total (TL) dan tinggi badan ikan (D.max) hasil tangkapan jaring cantrang KM. Bintang Jaya di Brondong Jawa Timur bulan September 2002

\begin{tabular}{|c|c|c|c|c|c|c|}
\hline \multirow{2}{*}{ No. } & \multirow{2}{*}{ Nama Lokal } & \multirow{2}{*}{ Nama Latin } & \multicolumn{2}{|c|}{ Panjang (TL) } & \multicolumn{2}{|c|}{ D. $\max$} \\
\hline & & & Kisaran (cm) & Frekuensi (ekor) & Kisaran (cm) & Frekuensi (ekor) \\
\hline \multirow[t]{2}{*}{1} & Golok-golok & Chirosentrusdorab & $21-30$ & 1 & $01-10$ & 10 \\
\hline & & & $31-40$ & 9 & & \\
\hline \multirow[t]{2}{*}{2} & Kerong-kerong & Therapon theraps & $01-10$ & 1 & $01-10$ & 8 \\
\hline & & & $11-20$ & 7 & & \\
\hline \multirow[t]{6}{*}{3} & Barakuda & Sphyraena genie & $21-30$ & 3 & $01-10$ & 17 \\
\hline & & & $31-40$ & 4 & & \\
\hline & & & $41-50$ & 1 & & \\
\hline & & & $51-60$ & 3 & & \\
\hline & & & $61-70$ & 3 & & \\
\hline & & & $71-80$ & 3 & & \\
\hline \multirow[t]{2}{*}{4} & Kapas-kapas & Achanthurus sp. & $11-20$ & 8 & $01-10$ & 8 \\
\hline & & & $21-30$ & 4 & $11-20$ & 4 \\
\hline \multirow[t]{2}{*}{5} & Kerapu & Epinephelus sp. & $11-20$ & 1 & $01-10$ & 9 \\
\hline & & & $21-30$ & 8 & & \\
\hline \multirow[t]{2}{*}{6} & Gulamah & Speudociena anoyensis & $11-20$ & 5 & $01-10$ & 13 \\
\hline & & & $21-30$ & 8 & & \\
\hline \multirow[t]{2}{*}{7} & Kurisi & Nemipterus nematophosus & $11-20$ & 5 & $01-10$ & 8 \\
\hline & & & $21-30$ & 3 & & \\
\hline \multirow[t]{2}{*}{8} & Beloso & Saurida tumbil & $11-20$ & 7 & $01-10$ & 9 \\
\hline & & & $21-30$ & 2 & & \\
\hline \multirow[t]{2}{*}{9} & Bondolan & Leiognathus splendeus & $11-20$ & 4 & $01-10$ & 8 \\
\hline & & & $21-30$ & 4 & & \\
\hline \multirow[t]{2}{*}{10} & Baji-baji & Saurida sp. & $11-20$ & 8 & $01-10$ & 9 \\
\hline & & & $21-30$ & 1 & & \\
\hline \multirow[t]{2}{*}{11} & Sebelah & Cynoglossus sp. & $11-20$ & 6 & $01-10$ & 9 \\
\hline & & & $21-30$ & 3 & & \\
\hline 12 & Petek & Leiognathus sp. & $11-20$ & 12 & $01-10$ & 12 \\
\hline \multirow[t]{2}{*}{13} & Kuniran & Upeneus sulphureus & $01-10$ & 6 & $01-10$ & 14 \\
\hline & & & $11-20$ & 8 & & \\
\hline \multirow[t]{3}{*}{14} & Kakap merah & Lutjanus altifrontalis & $01-10$ & 1 & $01-10$ & 12 \\
\hline & & & $11-20$ & 10 & & \\
\hline & & & $21-30$ & 1 & & \\
\hline 15 & Buntek & Cantigaster beneli & $11-20$ & 9 & $01-10$ & 9 \\
\hline \multirow[t]{5}{*}{16} & Layur & Trichiurus savala & $11-20$ & 2 & $01-10$ & 14 \\
\hline & & & $21-30$ & 4 & & \\
\hline & & & $31-40$ & 3 & & \\
\hline & & & $41-50$ & 4 & & \\
\hline & & & $51-60$ & 1 & & \\
\hline 17 & Kuro & Eletheromena titradaetylena & $11-20$ & 12 & $01-10$ & 12 \\
\hline 18 & Triger & Chaetodon sp. & $11-20$ & 11 & $01-10$ & 11 \\
\hline 19 & Selar & Selaroides leptoleppis & $11-20$ & 12 & $01-10$ & 12 \\
\hline 20 & Sardinella & Sardinella longiceps & $11-20$ & 10 & $01-10$ & 10 \\
\hline 21 & Biji nangka & Upeneus sp. & $11-20$ & 13 & $01-10$ & 13 \\
\hline 22 & Bambangan & Lutjanus sanguineus & $11-20$ & 1 & $01-10$ & 12 \\
\hline & & & $21-30$ & 11 & & \\
\hline 23 & Lencam & Lethrinus lentjam & $01-10$ & 1 & $01-10$ & 14 \\
\hline & & & $11-20$ & 13 & & \\
\hline 24 & Bilis & Stolephorus sp. & $11-20$ & 10 & $01-10$ & 10 \\
\hline 25 & Kiper & Siganus sp. & $01-10$ & 4 & $01-10$ & 11 \\
\hline & & & $11-20$ & 7 & & \\
\hline 26 & Ikan merah mt besar & Priacanthus tayenus & $11-20$ & 8 & $01-10$ & 14 \\
\hline & & & $21-30$ & 6 & & \\
\hline
\end{tabular}




\section{KESIMPULAN}

1. Salah satu alat tangkap ikan yang dioperasikan di perairan Pantai Utara Jawa adalah jaring cantrang.

2. Kapal yang dipakai untuk operasional penangkapan memakai jaring cantrang berukuran panjang (LOA) 9,50 m, lebar (W) 3,30 m, dalam (D) 0,60 m, bobot kotor $3 \mathrm{GT}$, dan mesin $16 \mathrm{PK}$.

3. Dimensi jaring cantrang di Brondong Jawa Timur umumnya setiap unit terbagi dalam 4 bagian utama.

4. Pengoperasian jaring cantrang dilakukan dengan sistim penyapuan secara horisontal, lama penurunan jaring sekitar 10 sampai dengan 15 menit per settingnya. Setelah penurunan jaring cantrang selesai langsung dilakukan penarikan yang waktunya antara 15 sampai dengan 30 menit per setting.
5. Hasil tangkapan jaring cantrang KM. Bintang Jaya dari 33 kali setting sebanyak $5.496,5 \mathrm{~kg}$, dengan laju tangkap rata-rata $166,56 \mathrm{~kg}$ atau $3,03 \%$.

6. Komposisi hasil tangkapan jaring cantrang terdiri atas 42 jenis ikan, hasil tangkapan dominan adalah gulamah (Pseudociena anoyensis) 634,8 $\mathrm{kg}$ atau $11,55 \%$.

7. Kisaran panjang berat (FL) dan (W), ikan hasil tangkapan jaring cantrang adalah $7,0-72,0 \mathrm{~cm}$ dan $100-1.560 \mathrm{~g}$.

\section{UCAPAN TERIMA KASIH}

Penulis mengucapkan terima kasih sebesarbesarnya kepada Bapak Drs. Kunto Purnomo, MS dan Drs. Bambang Sumiono yang telah memberikan saran dan koreksinya, juga kepada pengetik naskah, dan penerbit sehingga dapat terlaksananya tulisan ini. 